\title{
THE ROOT CAUSE OF VIOLENCE IN NIGERIA: THE NIGER DELTA CRISIS, A REFERENCE POINT
}

\section{Nwabuiro Ideyi}

\section{Abstract}

The world is a puzzle but the puzzle of all puzzles is man. Nothing that shows this nature of man more than his behaviour, which is full of contradictions. He loves and as well hates, builds and as well destroys, gathers and as well scatters, purifies and as well corrupts, refines and as well defiles, praises and as well condemns, etc, in his bid to make one thing or the other out of his wealthy-wretched existence. His whole existence is mostly informed by these contradictory actions of his, which have made him a big riddle. The focus of this work is on violence, one aspect of his behaviours, which exemplifies so much his enigmatic life. Man wherever he is, shows signs of violence either overtly or covertly in words or actions. He is either fighting or preparing to fight; either he is moody counting his loses of past fight or busy celebrating the dividends of his pyrrhic victory. To find him idle without being busy thinking about one ill-will, one complaint, one insult, one offence, one attack, one grudge or another against this or that person, this or that country, this or that idea, this or that opinion, etc, is like expecting a child hale and hearty who is not asleep to remain calm. That is not possible. Nigerians have often been roasted in the flame of violence. What is the root cause of this violence? What prices have Nigerians been paying for it? Is there anything that can be done to avert it completely or reduce the rate at which it occurs? These are main questions to be addressed in this paper.

\section{Introduction}

History's accounts of man's progress in the world show that it has not been a bed of roses for him. His rare moments of peace and tranquilly have often been shattered by deadly strokes of violence. His first experience of violence - self-inflicted violence was in the comfort zone of the Garden of Eden given to him by his Creator to be managed by his first human parents Adam and Eve. This happened when Adam and Eve were cast 
out for violating their Creator's order and warning that they should not touch, let alone taste a forbidden fruit specified for them at the Garden of Eden. But they were as free as air to eat any other fruit that caught their fancy (Genesis, Chap 1:28). The second experience was when Cain, their son, out of envy murdered his brother Abel whose offering was accepted while his was rejected by God. After these first and second experiences of violence held as the mother of violence, it has been violence everywhere in the world - North, South, East and West, it is the same song - violence.

Man knows that the peaceful world is far better than the violent world because development, which is positive change and which enhances, promotes and advances his well being is a direct function of peace. While backwardness, which distorts, disfigures, diminishes and impoverishes his well being, is a direct product of violence (war). Yet for the reasons that will be given latter, man could not restrain himself from entertaining thoughts and engaging in activities that provoke crises, violence and wars to his enormous cost and peril. A close study of man and his activities represent him as a being prone to antagonistic impulses. He is always either fighting or preparing to fight. His moments of peace are smokescreen, which in no distant time is pierced through by strokes of violence. His attempts at peace treaties are made futile by spasms of warmongers of whom sons and daughters of Adam and Eve are. Moody Bible Institute (1988:33) acknowledges this fact of man's life when, as paraphrased by Dawaki (2005:117-Shake Hands with DESTINY), writes: "It is said that in a total of 3,530 years of recorded civilization, only 286 years have been spent without war raging some place in the globe. Yet during that same period, about 8,000 peace treaties have been signed".

The knowledge of man's condition, according to Habu Dawaki, must have made Wag to describe "peace" as "the brief glorious moment in history when everybody stands around reloading"(2005:117). There is no doubt there is too much violence in the world to the extent that some people are thinking whether peace is not a stranger in the world. 
Their thinking equally receives a big support from a statement credited to Jesus Christ- the greatest friend of mankind especially the needy - the voiceless - the victims of the powerful of this world and who is also universally acknowledged as the greatest champion of peace, love, freedom and justice, when he says:

I came to bring fire to the earth, and how I wish it were already kindled:... Do you think that I have come to bring peace to the earth? No, I tell you, but rather! From now on, five in one household will be divided, three against two and two against three...(Luke, 12:49 -52).

As actions speak louder than words what Christ means is that he has come to wage fierce wars against the Herods, the Neros, the Hitlers, the Idi Amin Dadas, the Mobutus, the Abachas, the Nguemas, the Marcos, etc, of this world who made peace impossible and war inevitable; and thereby set their prisoners free and make life meaningful and comfortable for them.

Nigeria has a legion of disciples of these human monsters, which kill joy, wreck homes, abort dreams and destroy lives of their fellow human beings with impurity. Through their activities they have made Nigeria a paradoxical nation. A country reputed as a giant of Africa in name but a Lilliputian in fact. The richest country in the whole black race of the world in terms of human and material resources; but, alas! the poorest of the lots in terms of fair, just and equitable distribution of incredible amount of oil money rolling continuously into her coffers. Through their activities especially under Abacha regime, Nigeria was expelled from the Commonwealth of Nations and consequently treated as a pariah nation. Nigerians everywhere are seen as number one suspects in any scene of crime, and judged guilty before investigation commences. They are now especially the masses, refuges in their own country due to all forms of violence. Those who could afford it are leaving the country, the only country they can call theirs due to too much heat of violence and insecurity in all facets of life. They now regard the call on them, from the 
former head of State Gen. Mohammed Buhari to stay and salvage Nigeria together as hollow and pure bunkum.

The paper seeks to dig out the root cause or causes of this ugly situation that has enveloped Nigeria for years; to identify and lay bare its effects on individuals and the entire nation and to suggest a way out of the thick forest of hopelessness and frustration which they have been their lot since Nigeria's flag independence.

\section{Understanding Violence}

The term violence is nebulous because it often means more than what meets the eye and for that reason calls for down to earth explanation in order to get at what it really means. The need for this is to avoid narrow notion of what it stands for and connotes in all its ramifications. It has served as a common and effective tool used by both the oppressors and the oppressed in their efforts to achieve their respective aims. In other words, it has been conceived and used differently by different persons or group of persons for different ends. Therefore, it is important to begin with a question about its meaning.

What is violence? The term violence is derived from another term violate which is its verb form. To violate means among other things: to hurt, injure, break, disobey, infringe, invade, desecrate, pollute, profane, abuse, debauch, defile, deflower, outrage, ravish, transgress, damage, etc. Each of these synonyms of 'to violate' brings out the meaning of violence. Thus simply put violence means an act of destruction-any act of man that involves willful destruction. Man's belonging which could be destroyed range from his dreams, his work, his property, his freedom, his rights, his dignity, his moral principles, his life, his beliefs to other things he values, cherishes and works for their enhancement, advancement and protection. Or they could be things imposed on him such as harmful ideas, unjust principles, warped beliefs, laws, practices, structures, etc, which depreciate his human worth, enslave and dehumanize him to the level of toys and beasts of burden. He sees them as detrimental to his cherished values and decides to wage war against them in order to restore his endangered liberties and dignity. Both of them are 
victims of violence because willful destruction of what the victim has is involved. Throwing more light on what violence is, Robert McAfee Brown, an American human rights activist defines violence as:

Whatever violates another, in the sense of infringing upon or disregarding or abusing or denying that other, whether physical harm is involved or not, can be understood as an act of violence.... In the broadest sense then, an act that depersonalizes would be an act of violence, since... it transforms a person into a thing (1987:7).

In other words, violence could be physical or nonphysical but it involves damage of what the victim holds dear and thus reduces him or her to a level of a thing - to a sub-human being, if not outright destruction. As well, Helder Camara, the Archbishop of Recife, Brazil, in his own explanation of violence writes:

No one is born to be a slave. No one seeks to suffer injustices, humiliations and restrictions. A human being condemned to a sub-human situation is like an animal-an ox or a donkey - wallowing in the mud. Now the egoism of some privileged groups drives countless human beings into this sub-human condition, where they suffer restrictions, injustices, without prospects, without hope, their condition is that of slaves.

In other words, the victim is dehumanized to a level of a shadow of a human person. He or she is a mere property to those that push him or her into this sub-human situation to be used as a tool to satisfy their whims and caprices. His mind is bound to be full of bitterness and if he or she has not lost all the strength in him or her, he or she will revolt against the source of his or her enslavement.

Camara goes further to classify violence into three: first, the violence of injustice - this he describes as the mother of violence in human society; second, violence of revolt which he 
says to be a direct consequence of the former and third, the violence of repression-which he says to be a direct result of the latter and the deadliest form of violence because it is seized by those in power to suppress upheaval of the repressed people. The powerful do not hesitate to use any means considered effective no matter how outrageous it is to achieve their aim. So, violence in human society progresses from injustice to revolt and from revolt to repression. In whatever stage it exists, incalculable damages are inflicted on some persons and the entire society is worse for it.

\section{Incidents of Violence in Nigeria}

Nigeria is a human society as well as a sovereign state. Like every human society, it is a collection of people who have agreed to live, work and share their benefits and burdens of life together in their efforts to realize goals of their well being. They have realized that the goals of their well being, are easier and better attained in their joint efforts than in their separate efforts. So, human society (Nigeria inclusive) came into being solely to help its members to achieve their individual and collective goals. The overruling goal is that of their well-being. Their well-being is the purpose of their coming together to live and work for its attainment. Their well-being constitutes their needs such as peaceful atmosphere, access to basic needs like food, shelter, clothing, health, education, security, self-expression, just society, opportunities to work, etc. Save some parts of their earnings and invest them some for a better future; recognition of the humanity of every member, his right to live and develop himself or herself to the fullest extent possible; to set up families and bring up their children to become good members of the society, etc. Every society is charged with the responsibilities of making possible the attainment of the preceding needs of its members.

Nigeria has not shied away from the responsibility of helping its citizens to attain their individual and collective goals of their well-being. But the task has not been a happy-lucky one or a bed of roses. Rather the history of its efforts to that end has been a chequered one-full of ups and downs despite the fact that it is, comparatively speaking, well blessed by nature in terms of 
human and material resources. The people who have had the fortune or misfortune of presiding over the affairs of the country before and after its independence in 1960 have been bad managers who could not manage the resources of the country to the joy of all and to the sadness of none. The experience so far shows that Nigerian leaders know next to nothing in terms of just, fair and equitable distribution of the nation's commonwealth. Their failure in this important matter is attributed to their naked selfishness, greed, love of money, lust for power, craving for accumulation of wealth for themselves, their families, friends, godfathers and sycophants who helped them to get to their positions of power. Their activities continue to widen the gap between the rich (which they are) and the poor (which the Nigerian masses are) and thus create a nation of two nations - the nation of the rich and the nation of the poor. Thus frustration, hunger, poverty, despondency, grumble, ill will, etc, become the lots of the poor. While airs of superiority, luxury, flamboyant life, intimidation, arrogance, lordly behaviour, suppression of legitimate complaints, etc, become norms for the rich. In such a country, it is idle to expect peace and tranquility to be the order of the day instead of anger and violence.

In Nigeria incidents of violence are legion. Just a few will be mentioned as it is not in doubt that Nigeria has been bedeviled by this human virus. What is most important is how it can be stopped or reduced. The first incident of violence that flashed past the researcher's mind is slave trade. All of the events that have occurred in human history the one that has degraded, deformed and distorted human dignity in a large scale is slave trade. This alone has questioned, dismissed and made a mockery of man's claim to rationality, knowledge and civilization. In that scene man's inhumanity to man was given full expression. For in it, man made his fellowman a cargo, an object, a good, a toy to be used and discarded at will. In the hands of those who introduced this inhuman trade animal pets were treated with much love, respect and dignity than human cargos that could be stubborn at times. It is this man's inhumanity to man exhibited in various forms that made God to weep and to regret to have made man. 
Commenting on the evils of slave trade and its devastating effects on Africans as a whole Bassey W. Andah and Kunle Bolarinwa in the Introductory part of A Review Workshop write:

At the beginning of this current phase of man's inhuman treatment of man which has lasted well over five centuries, Africans were packaged like sardines and transported to distant lands to bear the yoke of slavery for the development of this "superior" race. In the process, millions died as they continue to die even to this day in the ghettoes of South Africa, U.S.A, South America and elsewhere (1994:2).

Nigeria was a victim of this inhuman trade introduced and championed by the western countries especially Portugal, Britain, France, etc, which questioned its culture, philosophy, world-view, principles, ideas of God and worship, family life, communalism, freedom, governance and other things that make human society desirable and distorted, disregarded, shredded and cast them away as barbaric. Alien ways of life were imposed on Nigerians and they were compelled through persuasion, deception, intimidation and force to accept them as gospel truth. The worst of all was the cream of its population made up of ablebodied men and women carried away to foreign land to work as slaves in the slavers' plantations. The damages done to Nigeria and Nigerians by this evil trade they are yet to recover from them as violent behaviour is the order of the day.

The second incident is imperialism with its offshootcolonialism. Imperialism as an economic and political theory was formulated in Europe to serve as "the rule of the powerful monopolies, trusts, combines and cartels controlled by the financial oligarchies of the various European countries, along with the consequent reduction of the market competition which characterized the earlier periods of capitalism. Abroad, for example, Africa, imperialism combined these features with foreign European control of the local apparatus of the state" (Nnoli, 1980:1). In other words, it was an economic strategy 
devised to control economic and market forces in the interest of the group that championed it. For Claude Ake a renowned economist "it is the economic control and exploitation of foreign lands arising from the necessity for counteracting the impediments to the accumulation of capital economy" (2002:20).

Imperialism funded and sustained colonialism in Africa as a rule of one country over another country. The rule was seen as an imposition by the latter since the former did not seek its opinion before exercising it. Britain imposed its rule on Nigeria and ruled solely to enhance, promote, advance and protect its economic interest at home and abroad. To achieve this an overruling interest, the colonized were seen as tools to be used and discarded at will; their humanity was not recognized and so with their freedom. No wonder Walter Rodney says: "Colonialism was a negation of freedom from the view point of the colonized (2004:244). Colonial administration in Nigeria did not hide its economic interest neither did it spare anything considered effective to promoting it no matter how despicable, disdainful, inhuman and immoral it was. Hence colonial experience in Nigeria from the view point of Nigerians was characterized by language of force, exploitation, cheating, fraud, murder, stealing, dehumanization, etc. Britain used deceit, persuasion and violence to nip at bud the natives' uprising against foreign rule.

The third is neocolonialism. Nigeria got its freedom (independence) from Britain in 1960 and attained the republican status in 1963. Some privileged Nigerians assumed the leadership of the new state. The Nigerian masses were beside themselves with joys as they were now to be ruled by their own people who had promised them heaven on earth. But to their utter confusion and disappointment, within a short period they noticed that the predatory character of their former taskmasters had already reappeared in the character of their present leaders. The differences were only in name and skin colour but ideas, thinking pattern, behaviour, actions and reactions were the same with those of colonial masters. It was a will to survive among the leaders- a will that brook no opposition; hence they engaged in war of words that latter resulted in the outbreak of Nigerian civil 
war. Before the outbreak of the war, the Nigerian nation witnessed crises, uprisings, upheavals, riots, demonstrations, strikes, fights, etc, in all facets of its life. The language of force was common and often translated into physical fight.

The fourth was the coup de a eta of 1966 organized by some Nigerian majors in the Nigeria army led by the late major Kaduna Nzeogwu. According to the coup plotters their reason was to ensure that Nigeria remained united and stable. In other words, to save Nigeria from politicians' divisive activities. The planners of the coup did not succeed in assuming the leadership of the country but it was assumed by another group in the army headed by the late Gen. Aguyi Ironsi, The coup was bloody as the prime minister the late Sir Abubakar Tarfawa Belawa was among the persons that lost their lives. The encounter coup that took place later in the year consumed the life of the head of state and other officers and men most of them from the eastern region - the region most of the first coup plotters hailed from. Gen. Yakubu Gowon (rtd), headed the new government.

The military incursion into power had militarized the entire nation. Force became their culture and violence was the constant outcome of their activities. Nigerians bled under the jackboot of the military rule for more than two decades it lasted in power. Nigerians's experience under the military rule made Samuel Aluko a renowned economist of international repute to say: "When a nation gives its rule to the military, that nation is finished. When a soldier captures a city, he loots it. When a soldier captures a country, what do you expect? He loots it" cited in (Odey, 1999: 36). When the military handed over power to a civilian government headed by Alhaji Shehu Shagari the looting of the national treasury continued unabated even till this day.

The fifth incident of violence is corruption galore in Nigeria. Corruption was promoted by the Shagari administration and popularized by the Babangida regime. When Shagari came into power, he acknowledged the existence of corruption in the country and lamented over the damage it had inflicted on the country. In his words:

I am ... dismayed to understand that corruption, fraud and smuggling are not only being 
institutionalized but are fast becoming a business pursuit in our country... those who rise through criminal records to the position of affluence are embraced by the society while merit, honesty and integrity are hardly recognized, according to the Nigeria Standard, November 1, 1983: page 11, cited by Odey (2001: 39).

Of all the evils that have tortured this nation none was or is more devastating as corruption. "Corruption distorts, deforms, corrodes and it destroys ... imposes injustices, it imposes dissatisfaction. It does not ensure equity; it does not ensure justice", (Odey, 51).

The Shagari administration was neck deep in corrupt practices. Under his administration nation's public properties were torched by fire to cover official fraud. For example, the tenstorey building, housing the federal ministry of Education, along Moloney Street, Lagos, was burnt down in 1980; Imo State Treasury Pay Office was burnt in April 1980. The Republic Building in Lagos, housing three federal ministries Information, External Affairs and Science and Technology were set ablaze on December 14, 1981. In Gongola State the Ministry of Agriculture and Co-operatives was burnt down in November 1981 to stop the probe into the fraud involving the loss of N1.9 million to the state. Hired political thugs razed down Anambra state Broadcasting Co-operation Transmitting Station in Enugu in 1982. In December 1982, the Accounts Department of the Federal Capital Development Authority in Abuja was set ablaze to cover up a fraud of N21 million (Odey, 2000: 18). All these happened in his administration despite his solemn promise to rid the country of corruption.

Corruption is the most violent crime against Nigeria and Nigerians. For it ensures that nothing made by man works well in Nigeria; it creates artificial scarcity, unemployment, loopholes for siphoning public fund abroad; it distorts reality, destroys moral values, mocks truth, justice, sincerity and selfless service; impoverishes the masses, pollutes the air, defiles relationship, 
stops growth and kills dreams, development and lives. It is evil and number one enemy of Nigeria.

The sixth incident is armed robbery. Neither in the homes, streets, markets nor highways are Nigerians safe nowadays because of frequent occurrence of armed robbery incidents. So goes the saying: "An idle hand is a devil's workshop". The unemployment problem, which now seems beyond remedy, has produced army of idle hands and some of them have decided to punish the society that fails to provide them with means of lifelihood and dignity by robbing its members of their property at gunpoint. The number of lives that have been wasted as a result of armed robbery is only God can tell the exact number. No Nigerian (including the armed robbers too) sleeps with two eyes closed. One is always disturbed by the thought of unexpected visitors, which can happen anytime. Insecurity of all sorts is now the fate of the country and its helpless people. The police cannot perform very well because they are overstretched by the amount of works that awaits them daily, by material and spiritual poverty that dampens their zeal to perform, and by dilapidated instruments of force at their disposal which are no match to the modern sophisticated weapons used by avoidable enemies of the society.

Seventh is the incident of violent language, which is common among Nigerians. Nigerians, as frustrated human beings suffering abject want in the midst of plenty, are always throwing at each other abusive words at slightest provocation. The bottled up anger is let go with light speed at a slightest provocation. With a little breach of normal social behaviour, a rain of unprintable words, phrases and sentences become inevitable consequences. For example, stepping on somebody's toes or pushing somebody unintentionally will attract abusive statements such as "Who is this evil", "Do it to your cursed mother", "Whoever that did this, it will not be well with you", "You are stupid", "You are a relic of the primitive people"., "You are a son of whore", etc. The frustrated minds are always full of evil thoughts and any opportunity is used to vent his or her anger. The virtues of "excuse me", "sorry", "take care", etc, which are appropriate forms of social behaviour are lost to most Nigerians. 
Eight is the incident of religious crisis. Nigeria, despite its insistence to be secular as contained in the constitution, the two major religions: Christianity and Islam, whose adherents love to fight themselves anywhere and at anytime observe religious tolerance only in paper. Hence the country is often roasted in the avoidable flame of religious crises with resultant loses of lives and properties. Religious tolerance a virtue upheld by civilized world is not for them and that is why Christians and Moslems see each other's religion as nothing. The religious leader in the Islamic fold Sheik Gumi was once quoted as saying in these choice words: "Christianity is nothing" (Soyinka, 1991:5). While almost every authority in the Christian fold is certain that "Islam is a warped religion". Each of these statements is a naked abuse of the opponents. Statements and acts such as these have made religious crises and wars most recurring decimal in Nigeria. Each of them sees the other as a sacrificial lamb to be destroyed at a slightest provocation. The religious leaders and the led are neck deep in this sin against God whom they claim to worship with all their hearts. God cannot be deceived. They have all gone astray heading to a place worse than hell unless they repent.

Ninth is the incident of communal or regional crises. The communal or regional crises are common events in Nigeria. Hardly a month passes without news about one communal crisis or another being carried as a headline story in any of the daily newspapers with soul-sapping violent clashes resulting in enormous loses of lives and property. When communal conflicts or crises are mentioned in Nigeria the following easily come to mind: the Gbaragolo and Sama conflict which occurred in February 1993, the clashes between communities in Benue in June 1993, the Andonis and Ogonis conflict in July 1993, the Ogoni and Okrika conflict from May to December 1993, the Jukuns and Tivs conflict in 1995, the Ijaws and Itsekiris conflict in 1997, the Ife and Modakeke conflict in August 1997, the Ezilos and Ezza conflict in June 2008, the Niger Delta crisis in the south-south part of the country and the federal government from 1960 to date and many other conflicts. Each of these conflicts is a pathetic show of violence in a country which needs peace said to be a catalyst of development more than any other 
country in the world given its backwardness in many areas of life.

Tenth is the incident of moral violence. This is the arrowhead of violent events because it is subtle, imperceptible but instigative of physical violent events. From the first to the ninth events are physical which are conceived, nursed, nurtured and brought about by the tenth-moral violence. The moral violence is an umbrella name housing violence of distrust, violence of injustice, violence of silence, violence of greed, violence of wickedness, violence of lies, violence of dishonestly, violence of ignorance, etc. A nation afflicted by moral violence is in a big trouble. Take for instance, violence of silence. This is said to be:

The violence of those who are in the position to speak for the oppressed, and whose voice could be heard and hearkened to, but who have decided to keep quiet and watch the predators destroy the nation and the people. It is like the violence of Pilate who washed his hands after condemning Jesus, thinking that he had become Innocent of his blood (Odey, 1999: 58).

This is the worst violence. A person in a position to solve a problem or suggest how to solve a problem knowing quiet well the weighty respect his voice carries but out of passivity, thought of personal safety, of one influence or the other decides to keep quiet or to grumble in the safety of his house is the worst form of violence. Man dies in such a person and his nation suffers violence that perhaps might have been avoided.

\section{Causes of Violence in Nigeria}

Literatures on causes of violence in Nigeria identify many factors among them are selfishness, greed, injustice, do-ordie politics, love of money, wealth, accumulation of wealth, revolt, repression, immorality and ignorance. One or more of these factors bring about every violent event that has taken place in Nigeria. 
On the preceding list the first factor is selfishness. Selfishness is a subtle but fertile soil for violence. Man is a social being-a being that lives, works and grows in the midst of others; a being that needs the assistance and encouragement of others to attain his goal. For that reason he has to consider others' interest in taking actions and everything he does. But when selfishness takes over him, he ignores totally or considers less this important aspect of his social life and focuses on self, his actions often become offensive to others and arouse in them negative reactions which must be violent in varying degrees. For example, the third term bid of the Obasanjo administration was a product of selfish desire. The former president Olusegun Obasanjo loved power borne out of his selfish- desire to remain in power until death strikes him in order to protect and preserve his wealth. That was why he and the people who were stupid to believe him worked to amend the constitution midway to elongate his tenure in office. Some Nigerians noticed that the bid was a naked violence to the nation's constitution and their dignity, rallied round and said no. The rest is now history.

The second factor is greed. Greed is a social cancer said to be at work in a person when that person has excessive desire for something be it food, money, wealth or anything else, which in reality he or she does not need or needs as much. Often it is excessive and selfish desire for money, wealth, power, influence, etc, without thought about the after effects. Nothing is so stomach turning, soul sapping, morally revolting and violently provoking like the victims of these social viruses at parade. For in the national Assembly this cancer is noticed when the members of that legislative body begin to urge among themselves as what should be appropriate amount for their seating, standing, sleeping, awaking, talking, traveling, eating, drinking, womanizing, and other sundry allowances leaving the primary duty of legislation to suffer.

Also, when the people who by their education, position, influence, etc, are better placed to tell our leaders to stop destroying the only country we have but prefer to keep quiet having accepted money, or property or hope to get such from them. When voters who are supposed to use their votes to decide 
who should lead them and thus change their present and future of their children for better prefer to sell their votes for some cups of salt, rice, pepper or things like that from some politicians who are specialists in wrecking people's homes and lives. When lecturers prefer to award marks based on who among his students purchase his book or handout to who answer examination questions correctly. When the leaders of the Niger Deltans used their position to divert some money meant for the development of the region for their personal enrichment at the impoverishment of the people. Events such as these provoke anger and righteous indignation in the people against the perpetrators of these wicked acts.

The third is injustice. The common runs of mankind hold the view that nothing that makes easier and quicker a destruction of human society more than injustice. Once by omission or commission it is allowed to rear its ugly head in the society, its first port of attack is the web of human relations; second is the moral values like trust, truth, integrity, honesty, equity, peace, love, sincerity, respect for life and human dignity, for common patrimony; live and let live, etc, being the building bricks of the edifice called society; and third is justice which is the foundation of every human society. Society was built on the stone of justice and members of the society work to continue to maintain a just society. If out of negligence, selfishness, greed or the likes, justice develops winds and flees the shores of the society in question for injustice to take its place the society becomes vulnerable to violence and its disintegration is just a question of time. Odey (2006:49) supports this view when he writes: "If justice is put on the throne, peace and love will take their normal course. But if peace and love are planted where injustice is rooted, they will be choked".

Injustice as a social monster- as a cobra snake, it bares its fangs in many diverse ways in a society that harbors it. When leaders cease from rendering selfless service, pursuing common goals, making policies and engaging in activities that enhance, promote and advance people well-being and instead engage in corrupt practices to enrich themselves and build empires of wealth with public funds, injustice is on the throne. When a 
citizen of Nigeria who is qualified for a job on the basis of merit but he or she is deprived of it on the basis of his or her State of origin, sex, religion, tribe, lack of godfather or any other variable, it is a naked injustice. When the federal government started tinkering with the sharing formula between it and regions (now states) as provided in the constitution before the discovery of oil at commercial quantity from $50-50 \%$ to $100-0 \%$, to $87-13 \%$ respectively, it is injustice which gave birth to the Niger Delta crisis, now a heavy moral burden on the nation. When Nigerian masses are deprived of the right to choose their leaders at polls and told to go back to their houses, as their votes no longer count, it is violence on their human rights. When Nigeria is reduced to a pariah nation and Nigerians become common suspects and criminals in the international community due to the activities of their leaders, it is injustice on their humanity.

When Nigerian masses are forced to make peace with hunger, poverty and despondency in the midst of wealth cornered and monopolized by the elite and leaders who have at their disposal instruments of coercion to suppress the hapless masses in their righteous agitations, it is pure injustice. When the people in authority design salary scales in such away that a scandalous big gap exists between the highest and the lowest public servants in a manner that bestows affluence and higher standard of living on the former and poverty, misery and lowest living conditions on the latter, injustice is the case. Chinua Achebe confirms this scandalous disparity between public servants in Nigeria when he says: "The gap between the highest and the lowest public servants in Nigeria is one of the widest in the whole world. Certainly nothing like it occurs in any country worthy of respect" (1998: 26-27). Each of these arouses ill-feeling, anger and grudges and builds up as well in the victims the will to destroy the sources of these studied and executed violence on their human worth.

Fifth is poverty. Poverty is of two forms: material poverty and spiritual poverty. Poverty simply defined is a lack of what a human person needs to live a normal, true and genuine life. It is seen as a disease because it distorts person's worth and destroys his dignity and pushes him or her to live a miserable life. 
In material poverty a victim whether a person or a country lacks basic needs of life like food, shelter, clothing, access to health and education. In spiritual poverty a victim lacks love for others, does not have regard for others' interest, is always concerned with his own interest and prepared to ride roughshod over others to achieve his or its selfishness. Lying, dishonesty, blackmailing, conspiracy, greed, murderous impulse, etc, are his or its constant companions. In Nigeria where poverty is accommodated and crowned as a king, courtesy of bad managers of the country's abundant resources, the bitterness it arouses in the people has made the country vulnerable to violent eruptions with enormous costs in terms of lives and property.

Sixth is ignorance. Some people hold the view that injustice is the root cause of violence in human society. Reason? Justice is the foundation of society as well as its lubricant. Where it is ignored and made to flee, leaving its opposite - injustice around such a society is in a big trouble. It will be complaints, grudges, bitterness, fight and sometimes war. For justice says all must share what belongs to all. But injustice says might is right. It upholds survival of the fittest and panders to the interests of the powerful and makes a burn fire of the interest of the weak and needy. Injustice destroys social web of human relations and sows seeds of bitterness, rebellion and war. It is the fundamental source of violence.

It is obvious that injustice does a lot of havocs to human society but it is not true that it is the root cause of violence in the society. In human society ignorance is a primary problem and every other problem is secondary. Ignorance is lack of knowledge. The world is very large and man has known a few aspects of it. Also his knowledge about himself is next to nothing. And the little he knows intoxicates him and he loses it or impairs it in the course of his intoxication. Socrates said: "There is only one good that is knowledge, and one evil that is ignorance" (Dawaki, 2005: 51 - There is a place called TOMORROW). In his view knowledge is virtue and through it other virtues such as love, honesty, integrity, respect for others, respect for life, live and let live, justice, patience, humility, hardwork, etc, are revealed and their importance understood and 
appreciated. He equally said that evil is borne out of ignorance and no one knowingly does it (Uduma, 2000:246). Hence his advice to mankind expressed in these immortal words: "Man know thyself".

All the evils man has suffered, is suffering and will continue to suffer is because he does not know who he is, why he is, what he has come to do in the world, where he came from and where he goes after life. Also, man has little knowledge about all the consequences of his actions. If the Jew - the owner of the estate who asked his dogs to chase out the young and innocent Adolf Hitler of Germany who approached him for a job, knew that his action would make the adult Hitler to hate his race with passion and to kill six million of his kinsmen and women, he would not have done that. If Hitler too knew that his action would make him to live all his life in fear and die untimely by his own hand since his friends refused his request to get him killed, he would have refrained. Also the moral burden the federal government of Nigeria is now carrying on its head over the Niger Delta crisis is another example. If it had known that selfish tinkering with the sharing formula of 50\% each for the central and regions - the regions producing the resources respectively, would present to it a situation of considering to declare war as the president Yar' Adua is doing now on that parts of Nigeria oil is coming from, because of their insistence that justice must be done and seen to be done by all concerned, it would not have done that. It is the same with all other things done in Nigeria that have combined to make Nigeria unsafe for Nigerians.

\section{The Way Out}

An attempt to suggest the way out of Nigeria's myriad of problems is a Herculean task. It is an attempt undertaken solely in obedience to Sir Winston Churchill's diction: "The difficulty can be overcome immediately; the impossible takes a little longer", (Awolowo, 1981:32) So are Nigerian problems, they are difficult but resolvable, if Nigerians especially their leaders face the task with sincerity of purpose and dedication they call for. What to do? 
First, efforts should start from the source of all that is ugly, immoral, despicable, repressible, soul-sapping, wrong, bad, revolting, wicked, unjust, dehumanizing, depressing, regrettable, etc, in Nigeria which is ignorance. Ignorance is the evil of all evils - the mother and sustainer of all wrongs. The headquarter of all that is wrong with man in the world. Problem of ignorance is hard to solve because the problem solver doubles as the problem creator and hence the problem to be solved. And it is known as a fact that man is hardly a good judge in a matter his interest is involved. But in this case he has no other choice than to learn to be a good judge on which ever matter that comes his way whether his personal interest is involved or not.

Experience has shown that ignorance is darkness and the only thing that can disperse darkness is light, which is also called knowledge. Knowledge is a confirmed antidote to ignorance, for that, should be pursued with religious zeal. The means through which knowledge is acquired is education. Education is a process of training the young as well as the old members of society to acquire knowledge and skills. Knowledge of the world they live in, knowledge of themselves, their role in the world, the real meaning, purpose and essence of life. Skills with which to translate what they know into practice for the good of all. No wonder the great philosopher Plato says: "those who are rightly educated generally become good men” (Rusk, 1969:30) and good women too. In another forum Plato hammers that: "No man should bring children into the world, who is unwilling to persevere to the end in their nurture and education (Rusk, 6).

So, the purpose of education is to make good men and women out of members of the society; hence moral instructions are a necessity. Morally educated people are asserts to the society, propellers of development. This is because they know that the resources of the world are gifts to be shared by all, for that reason they remain sensitive to their needs, to others' needs and to the world's needs and work for the realization of all. Only morally educated person is sensitive in these ways. That is why Ocho (2005:67) says: "An educated person is one who is morally good and properly adapted to his society and who contributes meaningfully to the growth and development of the society". For 
that reason general education as a whole and moral education in particular should be compulsory and free to all Nigerians. The nation has the resources to embark upon this life-saving project if corruption is shown the exit way out of Nigeria.

Second, politics should be ridden of a do-or-die syndrome. Many Nigerians have a wrong notion of governance especially politicians. They see governance as an avenue to amass wealth with ease. This notion makes them to see politics, which is a process to produce those who will govern the state as a matter of life and death. In a civilized world, governance is a call for selfless service, a call to join the think-tank to think out ideas, make policies and draw programmes and implement the same with a view to building a nation state whose citizens will enjoy in full measure human rights and freedoms, meet their basic needs such as food, shelter, clothing, education, health and security and human needs like recognition of everyone's humanity, encouragement for self-initiative, self-reliance, free thinking and inquiry, development of one's talents to the fullest extent possible. This cannot be possible where people engage in warfare in the name of politics. Politics is a noble contest for power and like every other contest is has rules that the contestants must strictly obey and any breach must be frowned upon and sanctioned. Oladipo (75) feels sad about the lawless nature of Nigeria's politics when he writes:

This attitude is, to say the least, unfortunate. For even though politics is, in significant sense, a contest for power, it is not an unprincipled contest. Its practice in civilized societies involves some rules which are designed to ensure that the conciliation of interests in society which is its ultimate end is not done in an arbitrary manner. This accounts for the equal importance of the manner of installation of a political regime and the end it serves while in power in the determination of its legitimacy.

In other words, political contest must be carried out strictly under rules governing it and any breach of the rules no matter the circumstances and the person involved must not be 
condoned and the person involved must be punished to forestall future occurrence.

Third, morality should be enthroned in all facets of Nigeria's life and strictly observed by leaders and the led, the old and the young and the high and the low in the society. People's morality is the network of the principles of good or right behaviour. These moral principles guide the behaviour of the people and ensure that they live in peace, do their works and enjoy the fruits of their labour. The people's morality carries with it moral values to be observed. Like love, justice, trust, honesty, patience, integrity, hard-work, flair for knowledge, live and let live, altruism, being a brother's keeper, selfless service, etc, and immoral values to be avoided like murder, hatred, lying, stealing, idleness, backbiting, adultery, perjury, dishonesty, unjust acts, etc. Adherence to the former and abhorrence to the latter are what distinguish humans from brutes and make human society conducive to peace, security, progress and development. Without morality there will be no society and without society human beings will go back to the Hobbesian state of nature where life was "solitary, nasty, poor, brutish and short". Society will become a hellhole on earth and nobody will like to live in it.

Omoregbe (2003:197) emphasises the importance of strict adherence to society's moral values or codes when he writes:

Moral development and maturity on the part of the citizens of a country are pre-requisites for the development of that country....How can there be development in a country in which public funds are embezzled by those who control them and who a re supposed to use them for development / projects. How can there be development in a country in which self-interest is the dominant rule of action.

There is no where a country whose citizens are morally lax, who pay lip service to moral questions and make self-interest the rule will experience development. Without moral restrictions man is more dangerous than a monster and more brutal than a 
beast. Without strict enforcement of moral codes violence becomes the norm and only the fittest survives.

Fourth, poverty should be frowned upon, discouraged and sentenced to death if Nigeria is to be spared of spasms of violence. Poverty is both material and moral disease. In moral poverty, the victims lacks basic needs of life that make living worthwhile. Without food, shelter, clothing, access to education and health, a person ceases to be a human in the prosper sense of the word. He or she is excluded from human fold. The same with moral poverty, victims are problem creators and not problem solvers. They live on other peoples' sweats, build their fortunes on other peoples' misfortunes and feel happy to see others suffer. To avoid material poverty, Nigeria should create job opportunities for its army of unemployed but employable youths. Without opportunity to work a victim feels that society is against him or her and will wage war against it. To avoid moral poverty, corruption should be abhorred and seen to be abhorred by all and sundry. Leaders in particular should hands off corrupt practices before those who look up to them will follow their good example. They should rule by example and not by precepts. Nigeria has been lacking in the former but is inundated by the latter.

\section{Conclusion}

The preceding discussions have shown that violence is an ill wind of social phenomenon, which blows no one any good. In its aftermaths both its perpetrators and victims are losers. Also, that violence is not native to man but rather a consequence of his fallen nature, his frequent transgressions against the grains of his nature. It is his handiwork, for this reason, solution to that selfinflected problem must come from him. God's grace shall continue to shelter him but he (man) must work out his own salvation as regards violence.

The antidote to violence in any society is justice. Nigerians should allow justice to rule. In the rule of justice with its assistants - law, fairness, equity, and equality, no one lives in fear of another, no one bears ill-will against another, everyone acts as his brother's keeper, everyone thinks good of another and everyone's joys or pains become the joys or pains of all. In such 
a situation development moves in a light speed and Nigeria will be a place to live for Nigerians to develop their individual and collective endowments to the fullest extent possible and thus attain both self and collective fulfillment.

This may look like a dream. But, if it is a dream, it is one bound to come true if selfishness is replaced with altruism, ignorance with knowledge, greed with contentment, injustice with justice, a do-or-die politics with law-governed politics, poverty with wealth and every bad thought with good thought and bad action with good action. Nigerians the ball is now in your court to make or to mar your chance to develop Nigeria like other developed nations. 


\section{References}

Joseph I. Omoregbe (2003), Knowing Philosophy, Lagos: Jaja Educational Research and Publishers Limited.

Lawrence Offie Ocho (2005) Edited by I.O. Nwangwu et al, Issues and Concerns in EDUCATION and LIFE, Enugu: Institute for Development Studies.

Rust, R. R. (1969), Doctrines of the Great Educators, London: Macmillan.

Bassey W. Andah and Kunle Bolarinwa (1994), A Celebration of Africa's Roots and Legacy, Ibadan; Fajee Publications Limited.

Claude Ake (2002), A Political Economy of Africa, Nigeria: Longman Nigeria.

John Okwueze Odey (1999), The Days of the Jackals, Enugu: Snaap Press Limited.

Snaap Press Limited.

(2000), The Parable of a Wasted Generation, Enugu: (2001), The Anti-corruption Crusade - The Saga of a Crippled Giant, Enugu: Snaap Press Limited.

Obafemi Awolowo (1981), Voice of Wisdom, Akure: Fagbamigbe Publishers.

Okwudiba Nnoli (1978), Ethnic Politics in Nigeria, Enugu: Fourth Dimension publishers.

Olusegun Oladepo (1999), Beyond Survival, Ibadan: Hope Publications. Robert McAfee (1987), Religion and Violence, Philadelphia: The Westminster Press.

Walter Rodney (2004), How Europe Underdeveloped Africa, London: Bogle-L'ouverture Publications.

Wole Soyinka (1991), The Credo of Being and Nothingness Ibadan: Spectrum Books Limited. 